\title{
Palaeobatrachid frog from the late Miocene of Northern Caucasus, Russia
}

\author{
Elena V. Syromyatnikova
}

\begin{abstract}
Disarticulated remains of Palaeobatrachus sp. (Palaeobatrachidae) from the late Miocene (early Turolian, MN 11; about 8-7.5 m.y.) of Volchaya Balka and Gaverdovsky localities (Northern Caucasus, Russia) are described. Palaeobatrachus from Volchaya Balka and Gaverdovsky differs from other species of the genus by having four premaxillary teeth. It shows an intermediate dentition between pre-Pliocene palaeobatrachids with five or more premaxillary teeth and Pleistocene congeners with two or three premaxillary teeth. The variations in the frontoparietals and synsacra may indicate that two species of Palaeobatrachus co-existed in Volchaya Balka and Gaverdovsky. The wide contribution of the transverse processes of $\mathrm{V}_{7+8+9}$ in the sacral wings of Palaeobatrachus from Volchaya Balka and Gaverdovsky shows that palaeobatrachids probably reached an extreme degree of aquatic adaptation as early as the late Miocene or even earlier. The Caucasian Palaeobatrachus partly fills the late Miocene gap (MN 10-13) in palaeobatrachid distribution and extends the Miocene range of this family to easternmost Europe (European Russia).
\end{abstract}

Elena V. Syromyatnikova. A.A. Borissiak Paleontological Institute, Russian Academy of Sciences, Profsoyuznaya ul., 123, Moscow, 117997 Russia; esyromyatnikova@gmail.com; sev@paleo.ru and Zoological Institute, Russian Academy of Sciences, Universitetskaya nab., 1, St. Petersburg, 199034 Russia.

Keywords: Anura; Palaeobatrachidae; Palaeobatrachus; late Miocene, Caucasus; Russia

Submission: 24 February 2018 Acceptance: 23 July 2018

\section{INTRODUCTION}

Palaeobatrachidae Cope, 1865, are common extinct anurans in Europe (Rage and Roček, 2003; Roček, 2013), which are known from the Late Cretaceous (e.g., Buffetaut et al., 1996; Blain et al., 2010; Blanco et al., 2015; Szentesi and Company,
2016) to the middle Pleistocene (e.g., Ratnikov, 1993, 1997, 2002; Wuttke et al., 2012). The Asian records include Palaeobatrachus sp. from the early Miocene and, possibly, Pleistocene of Anatolia (Claessens, 1997; van den Hoek Ostende et al., 2015) and from the late Miocene (Vasilyan et al., 2016) and Early Pliocene (Syromyatnikova, per-

Syromyatnikova, Elena V. 2018. Palaeobatrachid frog from the late Miocene of Northern Caucasus, Russia. Palaeontologia Electronica 21.2.30A 1-16. https://doi.org/10.26879/861

palaeo-electronica.org/content/2018/2276-palaeobatrachid-from-caucasus

Copyright: August 2018 Paleontological Society.

This is an open access article distributed under the terms of Attribution-NonCommercial-ShareAlike 4.0 International (CC BY-NC-SA 4.0 ), which permits users to copy and redistribute the material in any medium or format, provided it is not used for commercial purposes and the original author and source are credited, with indications if any changes are made.

creativecommons.org/licenses/by-nc-sa/4.0/ 
sonal observation, 2017) of Western Siberia. Currently, two genera of Palaeobatrachidae are recognized: Palaeobatrachus Tschudi, 1838 (about 11 species), and Albionbatrachus Meszoely, Špinar and Ford, 1984 (two species). The latter genus is based only on the frontoparietal, and its distinctions from Palaeobatrachus in other skeletal elements are not known. Thus, at present, the most diagnostic characters of Palaeobatrachidae are also characteristic of Palaeobatrachus. Since the discovery of palaeobatrachids, a large number of articulated skeletons, isolated bones, and tadpoles have been recovered from various localities, and a large number of species have been described (for reviews see Špinar, 1972; Sanchiz, 1998). The Palaeobatrachidae is thus among the well-studied families of extinct anurans. Most described Palaeobatrachus species (excluding Palaeobatrachus hiri, P. robustus, $P$. langhae, and $P$. eurydices) are represented by articulated skeletons from the Oligocene and early Miocene of Germany and the Czech Republic (Špinar, 1972). These taxa described based on well-preserved, articulated fossils cannot be easily compared to those typified on the basis of disarticulated bones. Thus, the taxonomy of Palaeobatrachus is still unclear. Because the validity of some species is questionable, several attempts of taxonomic revision have been undertaken (VergnaudGrazzini and Hoffstetter, 1972; Špinar, 1972; Sanchiz, 1998; Wuttke et al., 2012). Within the genus, the late Miocene palaeobatrachids are more poorly known and originate only from the localities of the MN 9: Götzendorf/Sandberg, Austria (Harzhauser and Tempfer, 2004), Rudabánya, Hungary (Roček, 2005), and Gritsev, Ukraine (Wuttke et al., 2012; Vasilyan et al., 2016).

The present study deals with the Palaeobatrachus remains from the late Miocene (early Turolian, MN 11) of Northern Caucasus (Russia). The described remains come from two nearly synchronous sites, Volchaya Balka and Gaverdovsky (see "Material and Methods"). Both localities produced a series of isolated skeletal elements, but most of them were collected from Volchaya Balka. The record of Palaeobatrachus from the late Miocene of Northern Caucasus is difficult to compare with those of articulated palaeobatrachid taxa and to interpret taxonomically. Nevertheless, this record provides important information on the morphology of the late Miocene Palaeobatrachus of Eastern Europe.

\section{MATERIAL AND METHODS}

The Palaeobatrachus remains were collected

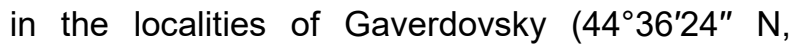
$\left.40^{\circ} 01^{\prime} 55^{\prime \prime} \mathrm{E}\right)$ and Volchaya Balka (=Fortepianka) (44 $\left.36^{\prime} 29^{\prime \prime} \mathrm{N}, 40^{\circ} 00^{\prime} 59^{\prime \prime} \mathrm{E}\right)$ on the opposing banks (right and left, correspondingly) of the Belaya River, near the settlement of Gaverdovsky, Maykop District, Republic of Adygea, Russia. The geological sections of the river banks expose continental sandy ocherous deposits of the Gaverdovsky Formation overlying shallow marine sediments of the Khersonian marine regional stage of Eastern Paratethys. Both localities were sampled from 2011 to 2013 by the joint field team of the Geological Institute of RAS (Moscow, Russia) and the Institute of Arid Zones SSC RAS (Rostov-on-Don, Russia). The Gaverdovsky and Volchaya Balka localities produced a diverse vertebrate and mollusk fauna. The micromammal assemblages of both localities studied by Tesakov et al. (2017) enabled their correlation to MN 11 of European continental scale. The material of Palaeobatrachus (as Palaeobatrachus sp.) from Volchaya Balka and Gaverdovsky was mentioned earlier (Syromyatnikova, 2016; Tesakov et al., 2017). The fossiliferous sediments at Gaverdovsky and Volchaya Balka are of lacustrine origin. Apart from fully aquatic palaeobatrachid frogs, the amphibian assemblage is characterized by semi- and periaquatic taxa such as the proteid Mioproteus, salamandrids Triturus sensu lato (several forms) and Chelotriton, ranid Pelophylax, and alytid Latonia (Tesakov et al., 2017).

In addition to the specimens of Palaeobatrachus described below, this study relies on published data on Albionbatrachus oligocenicus Venczel, Codrea, and Fărcaş, 2013, early Oligocene (Venczel et al., 2013); A. wightensis Meszoely, Špinar, and Ford, 1984, late Eocene (Meszoely et al., 1984); Palaeobatrachus diluvianus (Goldfuss, 1831), Oligocene-early Miocene (Špinar, 1972; Sanchiz, 1998; Roček, 2016); P. grandipes (Giebel, 1851), middle Eocene-lower Miocene (Špinar, 1972; Sanchiz, 1998; Smith, 2003; Roček, 2013); P. hauffianus (Fraas, 1909), early-middle Miocene (Roček et al., 2006); P. langhae (Fejérváry, 1917), early Pleistocene (Fejérváry, 1917; Venczel, 2000); P. luedecki Wolterstorff, 1886, Oligocene-lower Miocene (Špinar, 1972; Sanchiz, 1998); P. laubei (Bieber, 1881), middlelate Oligocene (Špinar, 1972; Sanchiz, 1998; Roček, 2013); P. novotnyi Spinar, 1972, Oligocene (Špinar, 1972); P. robustus Hossini and Rage, 2000, early Miocene (Vergnaud-Grazzini and Hoff- 
stetter, 1972; Hossini and Rage, 2000); P. tobieni (Wuttke in Sanchiz, 1998), middle Eocene (Sanchiz, 1998; Wuttke et al., 2012); P. hiri Venczel, 2004, middle Miocene (Venczel, 2004; Venczel and Sţiucă, 2008; Venczel and Hir, 2013); P. gigas (Meyer, 1852), late Oligocene (Špinar, 1972); $P$. eurydices Villa, Roček, Tschopp, van den Hoek Ostende and Delfino, 2016, early Pleistocene (Villa et al., 2016); Palaeobatrachus sp. from Rudabánya, late Miocene (Roček, 2005); Palaeobatrachus sp. and Palaeobatrachus cf. grandipes from Enspel, late Oligocene (Roček and Wuttke, 2010). $P$. occidentalis from the late Maastrichtian and early Paleocene of North America (Estes and Sanchíz, 1982; Gardner, 2008) is not used in comparison since its generic assignment is questioned Roček, 2013). The characteristics of some "problematic" species (i.e., P. grandipes, P. luedecki, P. laubei, and $P$. novotnyi), which are used in comparison are scored according to the most recent published observation (Villa et al., 2016) and personal communication (Roček et al., pers. comm., 2018

$P$. langhae is used here only for material from the type-locality (Betfia, Romania). The other material assigned to $P$. langhae or $P$. cf. langhae (Młynarski, 1960, 1962, 1977; Vergnaud-Grazzini and Mlynarski, 1969; Sanchíz and Młynarski, 1979; Hodrová, 1981, 1982a, 1982b; Ratnikov, 1997, 2002; Venczel, 2001) deserves a taxonomic revision (Roček et al., pers. comm., 2018). The SEM (scanning electron microscope) photographs were taken with a Cambridge CamScan-4 in the Paleontological Institute of the Russian Academy of Sciences (Moscow, Russia). The anatomical terminology mainly follows those of Bolkay (1919), Sanchiz (1998), and Roček et al. (2015). All fossil material of Palaeobatrachus from Volchaya Balka and Gaverdovsky is deposited in the Geological Institute of the Russian Academy of Sciences, Moscow (GIN hereafter).

\section{SYSTEMATIC PALEONTOLOGY}

\section{Order ANURA Fischer, 1813 Family PALAEOBATRACHIDAE Cope, 1865 Genus PALAEOBATRACHUS Tschudi, 1838}

Type Species. Palaeobatrachus diluvianus (Goldfuss, 1831), by monotypy.

\section{Palaeobatrachus sp. Figures 1-5}

Material. Gaverdovsky locality: two frontoparietals (GIN 1144/210-211); one sphenethmoid (GIN 1144/212); one premaxilla (GIN 1144/213); three maxillae (GIN 1144/214-216); six angulars (GIN 1144/217-222); one clavicle (GIN 1144/223).

Volchaya Balka locality: five frontoparietals (GIN 1143/330-334); four sphenethmoids (GIN 1143/ 335-338); four premaxillae (GIN 1143/339-342); 10 maxillae (GIN 1143/343-352); two nasals (GIN 1143/353-354); two squamosals (GIN 1143/355$356) ; 11$ angulars (GIN 1143/357-367); three presacral vertebrae (GIN 1143/368-370); six synsacra GIN 1143/371-376); one urostyle (GIN 1143/377); four coracoids (GIN 1143/378-381); two scapulae (GIN 1143/382-383); three humeri (GIN 1143/384386); nine ilia (GIN 1143/387-395).

Description and Comparison. The frontoparietal (Figure 1.1-14) is represented by fragments of the anterior and posterior parts of the bone. The fragments of the anterior half of the frontal part of the bone (Figure 1.1-4; GIN 1144/210 and 211) are flat and smooth dorsally. In other palaeobatrachids (except Albionbatrachus; Roček et al., 2015), the frontoparietal is unsculptured dorsally. The anterior end of the bone is not preserved in all specimens. The pineal canal in the GIN $1144 / 210$ is directed anteriorly and positioned in the posterior third of the preserved part of the bone. The presence of the pineal canal seems to suggest that the bone does not belong to a fully grown individual or may be pedomorphic. In a larger specimen (GIN 1144/ 211), the pineal foramen is minute, which might indicate that this individual is older than GIN 1144/ 210. The depression on the anterior part of the dorsal surface, which is known in some species $(P$. langhae, $P$. diluvianus, $P$. hiri, and $P$. novotnyi), is absent in all specimens. The middle part of the bone is slightly narrowed in the interorbital region. Low and smooth parasagittal ridges delimit the frontoparietal table laterally. They are widely separated from each other but deflected laterally and become vestigial towards the anterior margin of the bone. The posterior part of the bone can be reconstructed based on fragments (Figure 1.5-10) as only slightly widened and rounded posteriorly (Figure 1.11). Like the previously described specimens, it is flat and smooth dorsally. The parasagittal ridges are smooth and rounded. The paraoccipital processes are poorly developed. The transverse ridge is very shallow but not absent as in $P$. eurydices (Villa et al., 2016) and P. langhae (Fejérváry, 1917). Thus, the frontoparietal table is not clearly outlined. In GIN 1143/333, the posterior part of the frontoparietal table is clearly outlined and widened (Figure 1.12-13). The transverse ridge is clearly visible and reconstructed as concave (Figure 1.14). In the ventral view, a striated 


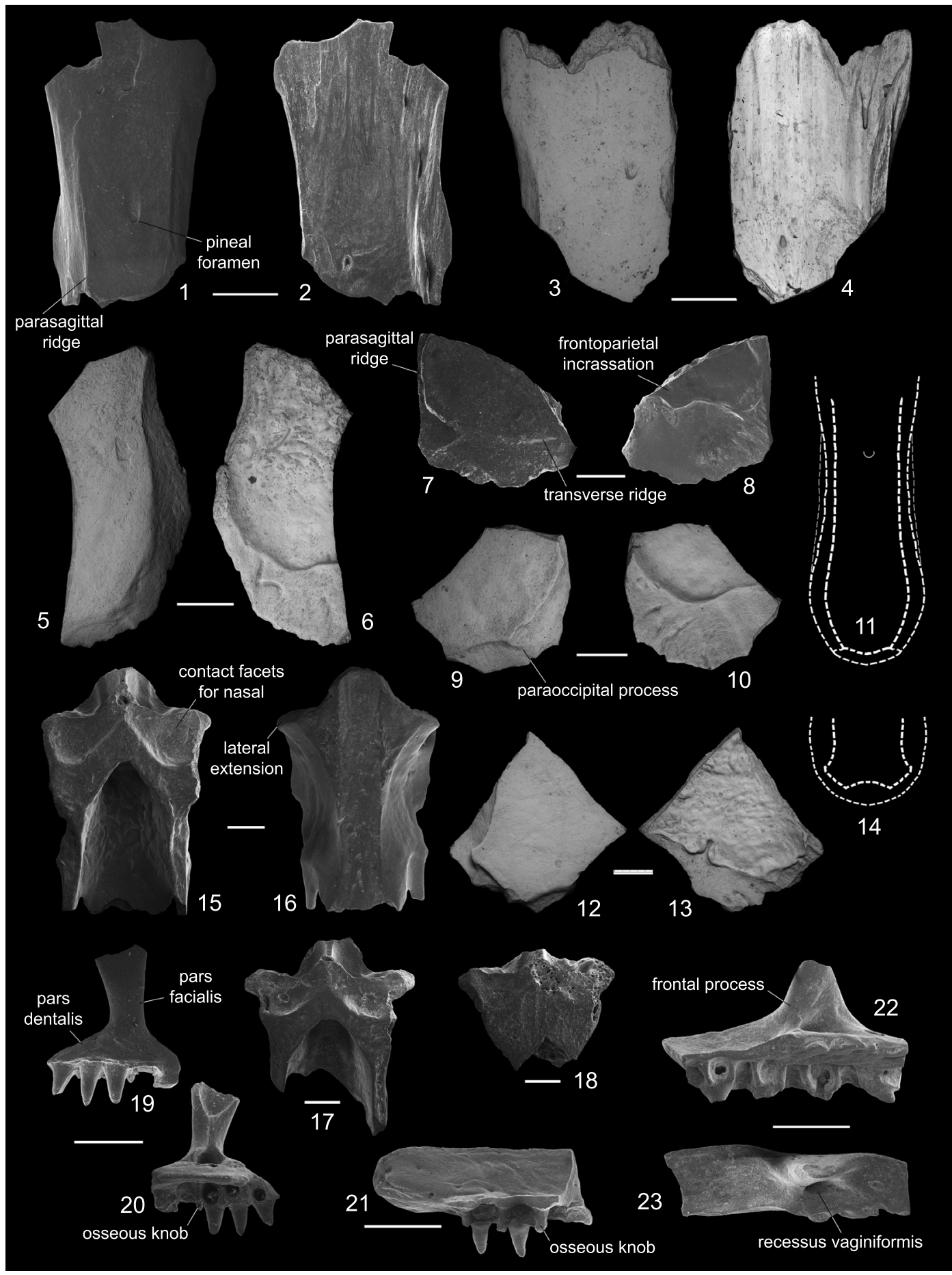

FIGURE 1. Palaeobatrachus sp.; late Miocene, early Turolian; Russia: 1, 2 - frontoparietal, GIN 1144/210: 1 - dorsal view, 2 - ventral view; 3, 4 - frontoparietal, GIN 1144/211: 3 - dorsal view, 4 - ventral view; 5, 6 - frontoparietal, GIN 1143/330: 5 - dorsal view, 6 - ventral view; 7, 8 - frontoparietal, GIN 1143/331: 7 - dorsal view, 8 - ventral view; 9,10 - frontoparietal, GIN 1143/332: 9 - dorsal view, 10 - ventral view; 11 - reconstructed frontoparietal based on GIN 1143/330-332; 12, 13 - frontoparietal, GIN 1143/333: 12 - dorsal view, 13 - ventral view; 14 - reconstructed frontoparietal based on GIN 1143/333; 15-16 - sphenethmoid, GIN 1143/335: 15 - dorsal view, 16 - ventral view; 17 sphenethmoid, GIN 1143/336, dorsal view; 18 - sphenethmoid, GIN 1143/337, dorsal view; 19, 20 - premaxilla, GIN 1143/339: 19 - labial view, 20 - lingual view; 21 - right maxilla, GIN 1143/343, lingual view; 22-23 - right maxilla, GIN 1143/344: 22 - lingual view, 23 - dorsal view. The specimens under figures 1-4 are from Gaverdovsky locality; 5-23 - from Volchaya Balka locality. Scale equals $1 \mathrm{~mm}$. The Figures 1.11 and 1.14 out of scale. 

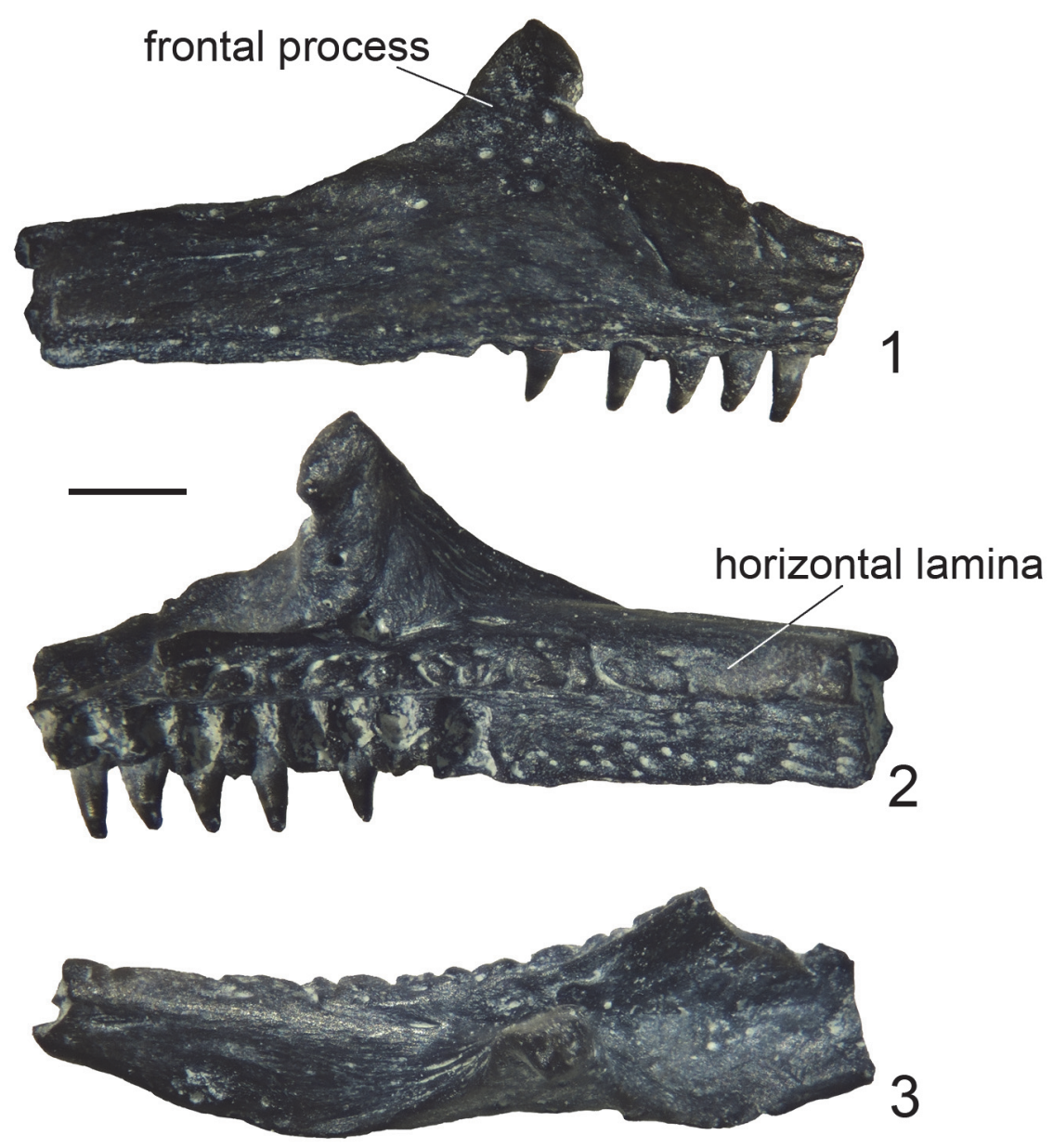

FIGURE 2. Palaeobatrachus sp.; late Miocene, early Turolian; Russia: 1-3 - right maxilla, GIN 1143/345: 1 - labial view, 2 - lingual view, 3 - dorsal view. The specimen is from Volchaya Balka locality. Scale equals $1 \mathrm{~mm}$.

area is present along the posterior and posterolateral parts of the incrassation, which are the sutural surfaces for the sphenethmoid and otoccipital bones correspondingly. As was recently shown (Roček et al., 2015), the shape of the frontoparietal and ridges can change during development. Thus, presence of the smooth ridges and the pineal foramen together with the small size of most of the described specimens may suggest that they belong to juvenile individuals or pedomorphic species. But GIN 1143/333 differs from them in having a larger size and shape of the posterior part of frontoparietal table. Thus, GIN 1143/333 either belongs to a fully-grown individual or to another species, which co-existed with Palaeobatrachus sp. in Volchaya Balka and Gaverdovsky.

The sphenethmoid (Figure 1.15-18) is represented by one complete and four incomplete speci- mens, which are missing the posterior part. The bone is robust and elongate, which is characteristic of all palaeobatrachids (Roček, 2013). As in most other Palaeobatrachus species (except $P$. hiri), it is not fused with the parasphenoid. The lateral extensions of the sphenethmoid are well-developed as in other Palaeobatrachus species, except in $P$. eurydices and $P$. robustus, where these lateral extensions are very poor or absent (Hossini and Rage, 2000; Villa et al., 2016). The fenestra frontoparietalis tapers anteriorly and varies from rounded (Figure 1.17) to angled (Figure 1.18) in its apex. The antrum olfactorium is wide. It delimits the fenestra anteriorly and anterolaterally. The contact facets for the nasals are well-developed and separated by a low median ridge, as is known in most other palaeobatrachids (except for $P$. eurydices, in which contact facets for the nasals are not sepa- 


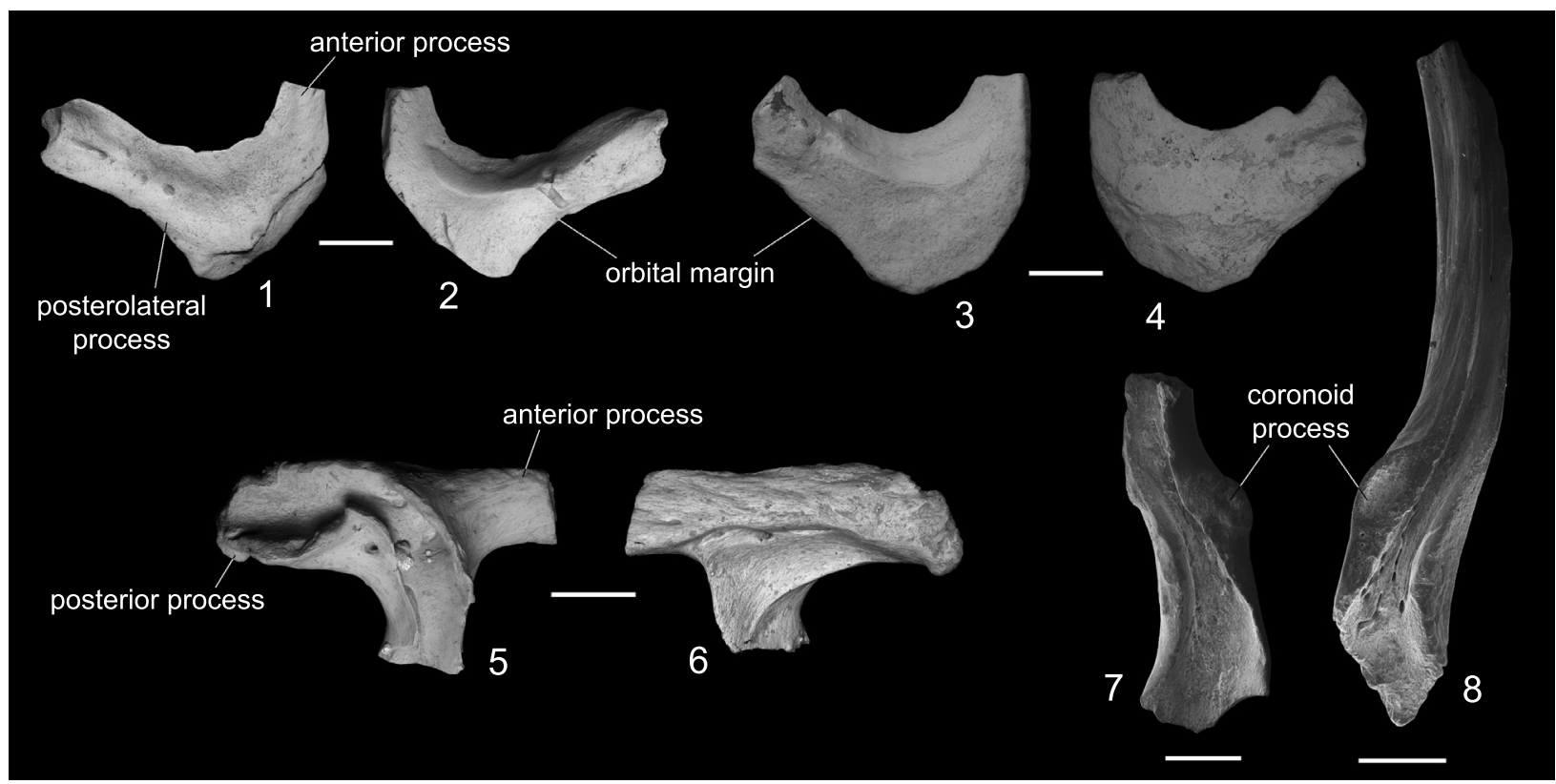

FIGURE 3. Palaeobatrachus sp.; late Miocene, early Turolian; Russia: 1-2 - right nasal, GIN 1143/353: 1 - ventral view, 2 - dorsal view; 3-4 - left nasal, GIN 1143/354: 3 - dorsal view, 4 - ventral view; 5-6 - squamosal, GIN 1143/ 355: 5 - medial view, 6 - lateral view; 7 - left angular, GIN 1143/357, dorsal view; 8 - right angular, GIN 1143/358, dorsal view. The specimens are from Volchaya Balka locality. Scale equals $1 \mathrm{~mm}$.

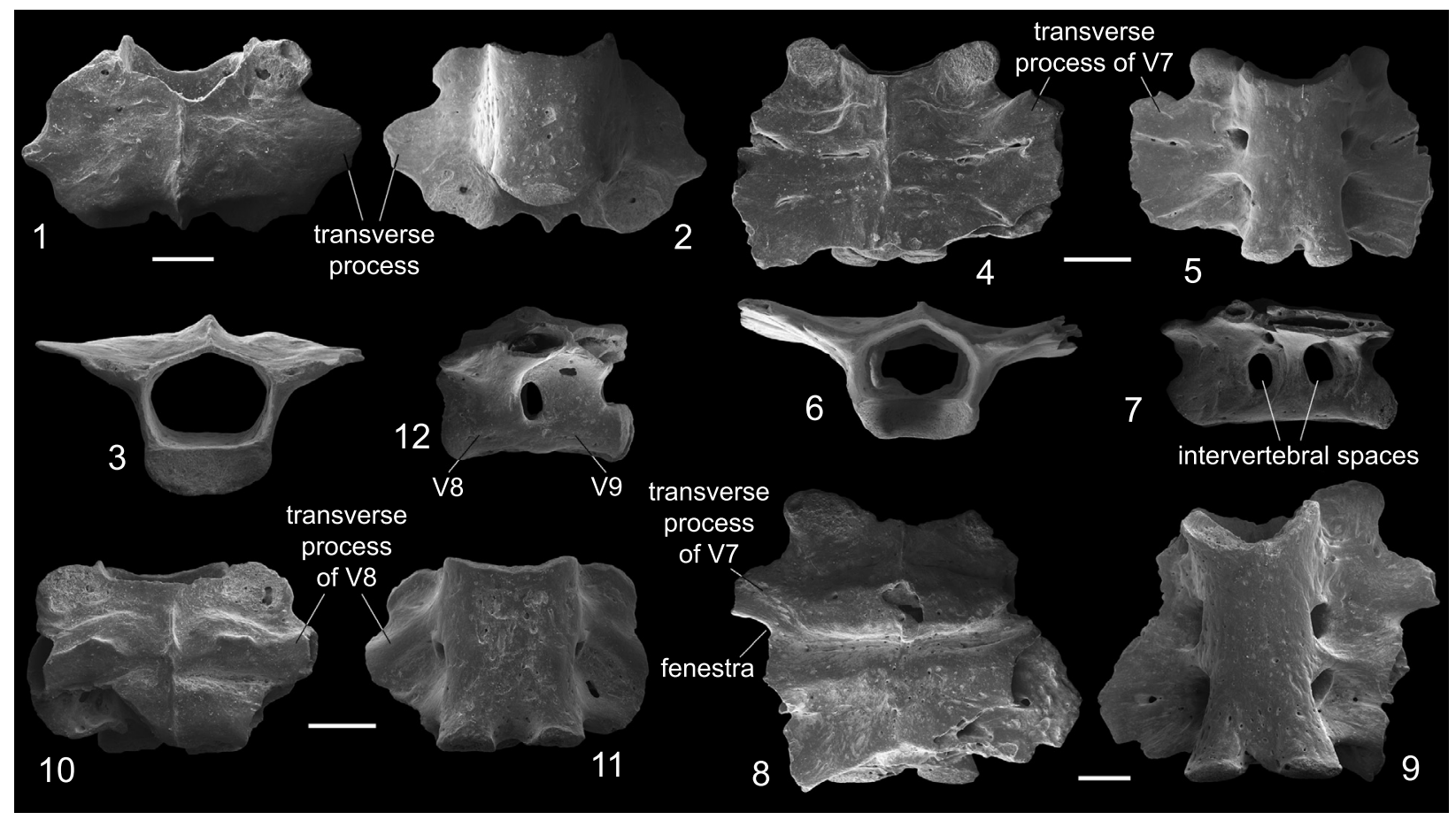

FIGURE 4. Palaeobatrachus sp.; late Miocene, early Turolian; Russia: 1-3 - presacral vertebra, GIN 1143/368: 1 dorsal view, 2 - ventral view, 3 - anterior view; 4-7 - synsacrum, GIN 1143/371: 4 - dorsal view, 5 - ventral view, 6 anterior view, 7 - lateral view; 8, 9 - synsacrum, GIN 1143/372: 8 - dorsal view, 9 - ventral view; 10-12 - synsacrum, GIN 1143/373: 10 - dorsal view, 11 - ventral view, 12 - lateral view; The specimens are from Volchaya Balka locality. Scale equals $1 \mathrm{~mm}$. 


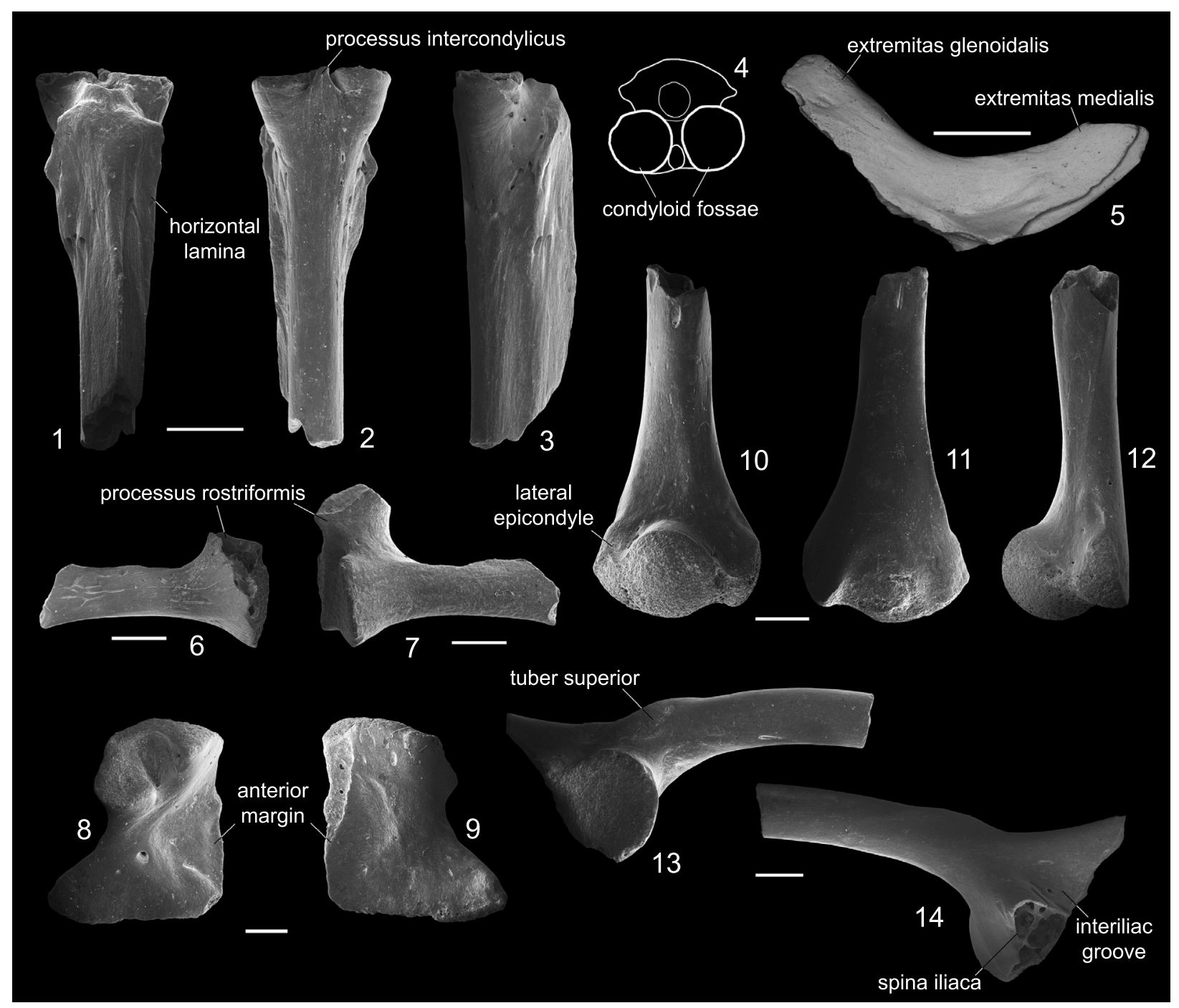

FIGURE 5. Palaeobatrachus sp.; late Miocene, early Turolian; Russia: 1-4 - urostyle, GIN 1143/377: 1 - dorsal view, 2 - ventral view, 3 - lateral view, 4 - anterior view; 5 - left clavicle, GIN 1144/223, dorsal view; 6 - left coracoid, GIN 1143/378, ventral view, 7 - right coracoid, GIN 1143/379, ventral view; 8, 9 - left scapula, GIN 1143/382: 8 - dorsal view, 9 - ventral view; 10-12 - right humerus, GIN 1143/384: 10 - ventral view, 11 - dorsal view, 12 - medial view; 13, 14 - right ilium, GIN 1143/387: 13 - lateral view, 14 - medial view. The specimens under figures 1-4, 6-14 are from Volchaya Balka locality; 5 - from Gaverdovsky locality. Scale equals $1 \mathrm{~mm}$.

rated; Villa et al., 2016). Ventrally, the contact area for the parasphenoid is visible as a deep median groove extending beyond the anterior border of the bone and delimited by ridges. The groove is slightly expanded posteriorly (in contrast to $P$. eurydices) The anterior part of the incisura semielliptica does not approach the anterior border of the bone. The contact surfaces for the frontoparietal and parasphenoid are nearly smooth or slightly striated. The lamina supraorbitalis is well developed.

The premaxilla (Figure 1.19-20) is represented by five specimens - two complete and three with partly missing teeth. The pars dentalis is relatively long (longer than that of $P$. eurydices), bear- ing four teeth on its medial part in all specimens. Other species of Palaeobatrachus usually have a large number of tooth positions, that is, five to eight (up to 10 in $P$. hiri), or the number of tooth positions is reduced (two or three in $P$. eurydices). The lateral part of the premaxilla is toothless as in most other Palaeobatrachus species (except $P$. hiri, $P$. gigas, and $P$. tobieni). The teeth are conical and slightly curved lingually with dark pigmentation at their tips. At the bases they are separated with osseous knobs, as is characteristic of palaeobatrachids. The lamina horizontalis is prominent lingually at its medial part. In contrast to the pars dentalis, the pars facialis is relatively small, wid- 
ened dorsally and ventrally, but slightly broken off in its tip. Interiorly, the deep groove extends along the pars facialis.

The maxilla is represented by a large portion of the bone and various small fragmentary parts (Figures 1.21-23, 2). The maxillary teeth are curved lingually with osseous knobs at their bases, typical for Palaeobatrachus. The tips of the tooth are characterized by dark pigmentation as in other Palaeobatrachus (Roček, 2013). The anterior part of the bone (Figure 1.21) is toothless and rounded at its tip. The numbers of tooth positions of maxilla are unclear. The most completely preserved specimen (Figure 2) has eight tooth positions. Based on all available specimens, the maxilla had about 1012 tooth positions. The frontal process is thickened and triangular in shape and varies from vertically directed (Figure 1.22) to inclined anteriorly (Figure 2). In the latter case, the posterior part of the frontal process is straight, whereas the anterior part is irregular and slightly bent labially. At the base of the frontal process, a deep and wide recessus vaginiformis is visible (Figure 1.23). The orbital margin of the bone is straight. The lamina horizontalis is broad and irregular in the anterior part of the bone and narrows gradually posteriorly. Dorsally, the anterior portion of the lamina horizontalis (anterior to frontal process) is broad and concave, whereas the posterior portion (posterior to the frontal process) is flat and narrow (Figure 2.3). The dentigerous portion of the bone terminates before (Figure 2.2) or near (Figure 1.22) the level of the posterior end of the frontal process. This indicates that the orbital portion of the bone was mostly toothless. Within other Palaeobatrachus species, the reduced dentition on the maxillae (i.e., the dentigerous portion of the bone terminates before the posterior end of the frontal process) is characteristic of $P$. eurydices, whereas in other species (e.g., P. hiri), dentition is not reduced (i.e., the dentigerous portion of the bone extended behind the posterior end of the frontal process).

The nasals (Figure 3.1-4) are represented by two crescent-like specimens. GIN 1143/353 (Figure 3.1-2) is most complete with only the anterior process slightly broken off at its tip. Although incomplete, the anterior process is straight and relatively short (shorter than the suture with the frontoparietal). The posterolateral process is wider than the anterior process and terminated by a straight margin. The posteromedial margin is widely rounded, whereas the orbital margin is only slightly concave (Figure 3.2) or straight (Figure 3.3). There is an oval depression on the ventral surface of the posterolateral process of the GIN 1143/354 (Figure 3.4) similar to the depression described in P. hiri (Venczel, 2004), but in Caucasian Palaeobatrachus, it is shallower and not clearly outlined.

The squamosal (Figure 3.5-6) is represented by the lamella alaris only. The posterior process (= processus posterodorsalis) of the lamella alaris is complete and relatively wide (wider than the anterior process). The anterior process (= processus zygomaticus) is incomplete but was obviously narrow. The processus posterolateralis is broken off at its base. The squamosal is generally similar to those of other Palaeobatrachus but differs from $P$. hiri in having a wider processus posterodorsalis and from P. laubei (Špinar, 1972) in having a narrow processus zygomaticus.

The angulars (Figure 3.7-8) are highly variable. The surface of the bone looks smooth, without the shallow grooves known in $P$. robustus (Hossini and Rage, 2000). As in other species of Palaeobatrachus, the coronoid process is dorsoventrally compressed (Roček, 2013). It continues distinctly posteriorly or is shortened, usually concave in the dorsal surface (Figure 3.8), and rarely either flat or slightly convex (Figure 3.7). It can be divided into two small fossae. In some specimens, the coronoid process is inclined medially. According to Hossini and Rage (2000), this variation might represent sexual dimorphism. The groove for Meckel's cartilage is narrowed at the level of the coronoid process. A tubercle described in P. eurydices and A. oligocenicus (Venczel et al., 2013; Villa et al., 2016) is usually absent, but visible in GIN 1143/357 (Figure 3.7). As in P. eurydices, this tubercle is present only in one specimen. The tubercle inferred to be the insertion surface of musculus levator mandibulae posterior subexternus (Venczel et al., 2013). The extremitas spatulata is wide and rounded posteriorly (in contrast to short and broad in $P$. eurydices).

The presacral vertebra (Figure 4.1-3) is procoelous. The condyle and cotyle are crescentic. In ventral view, the centrum is dorsoventrally compressed as in other Palaeobatrachus (Roček, 2013). It is long (contra to $P$. diluvianus). The prezygapophyses of the described vertebra are rounded and prominent anteriorly beyond the level of the anterior margin of the neural arch. The neural arch is deeply concave anteriorly and extends slightly posteriorly beyond the level of the postzygapophyses, forming a small spike. The neural ridge is poorly developed. The transverse processes are broken off at their bases. 
The synsacrum (Figure 4.4-12) is represented by several incomplete elements, among which usually three $\left(V_{7+8+9}\right)$ vertebrae are fused. In all specimens, the centra are fully fused and intercentral sutures are indiscernible, indicating fully grown individuals. In ventral view, the surface of the centra is smooth, as in other Palaeobatrachus (Špinar, 1972). The neural arches of all vertebrae bear the low neural ridges. Laterally, intervertebral spaces for spinal nerves are widely open on each side of the bone (Figure 4.7). The transverse processes of all specimens are broken off in their distal parts, so the shape of the synsacral wings is unclear. In the largest specimens (which appear to be adult; Figure 4.4-9), $V_{7}$ is fully fused with $V_{8+9}$. The transverse processes of $V_{7}$ are well-developed and fully fused to other processes $\left(V_{7+8+9}\right)$. The traces of fusion of the transverse processes are partly visible in dorsal view and invisible in ventral view. The small fenestrae remain open between the pedicles of each part of the synsacral wing. The one revealed synsacrum comprises only $V_{8}$ and $V_{9}$ vertebrae, which are fused by the centra and transverse processes $\left(\mathrm{V}_{8+9}\right.$; Figure 4.10-12). This may indicate that two species of Palaeobatrachus co-existed in Volchaya Balka and Gaverdovsky. According to recent data (Villa et al., 2016; Roček et al., pers. comm., 2018), several types of synsacrum are known in Palaeobatrachus. Among them, either two $\left(V_{8+9}\right)$ vertebrae are fused together or three vertebrae $\left(V_{7+8+9}\right)$ are fused. In the latter case, the transverse processes of $V_{7}$ contributing or not to sacral wings.

The urostyle (Figure 5.1-4) is represented by the only specimen damaged in its posterior end. The median crista is low or almost absent in its anterior part and increases posteriorly. Some tuberosity is present on the dorsal surface of the bone. The ventral margin of the bone is straight. The two condyloid fossae are clearly separated from each other by the prominent processus intercondylicus (Figure 5.4). The processus intercondylicus is present in $P$. hiri, $P$. eurydices, and Palaeobatrachus sp. from Rudabanya (Roček, 2005). It is also present in some Pliocene Palaeobatrachus from Ivanovce (Hodrová, 1982a). The canalis coccygeus in the described urostyle is rounded and narrowed (narrower than the diameter of the condyloid fossae). The horizontal laminae are thin and as wide as the anterior part of the bone. Some variation in the length and shape of laminae is observed on both sides of the specimen, which is longer and wider on the left side of the bone and shorter and narrower on its right side. The transverse processes are absent, as in most other Palaeobatrachus species (present in P. langhae; Fejérváry, 1917).

The clavicle (Figure 5.5) is represented by an almost complete bone with two branches: the complete extremitas glenoidalis and the extremitas medialis with a missing medial end. The extremitas glenoidalis is relatively short. The sulcus cartilagine precoracoidealis extends all along its posterior margin and is widely open dorsally on the distal end of the medial branch.

The coracoid (Figure 5.6-7) is represented by four incomplete specimens. The processus rostriformis is incomplete, but based on the best preserved specimen it is reconstructed as thick and robust. The presence of the processus rostriformis is characteristic of all Palaeobatrachus (except $P$. tobieni; Wuttke et al., 2012). The pars glenoidalis is broken off in its medial end, but it seems that it was relatively short and thick. Its anterior margin bears a tiny crista, which is lower than in $P$. eurydices.

The scapula (Figure 5.8-9) is represented by two complete specimens. As in other species of Palaeobatrachus (Špinar, 1972), it is short and wide. Its posterior margin is concave, whereas the anterior margin is almost straight as in most other Palaeobatrachus species (except $P$. diluvianus and Palaeobatrachus sp. from Rudabanya). The sinus interglenoidalis is absent, but the pars glenoidalis and pars acromialis are separated partly by a clear groove, as is known in other Palaeobatrachus species.

The humerus (Figure 5.10-12) is represented only by three portions of the distal part. The humeral ball is slightly shifted laterally from the axis of the diaphysis. The epicondyles are approximately equal in size. On the ventral face of the lateral epicondyle (= epicondylus radialis), an elongate and low radial tubercle is present. The fossa cubitalis ventralis is absent as in most other palaeobatrachids (except P. tobieni; Wuttke et al., 2012).

The ilium (Figure 5.13-14) is represented by several incomplete specimens comprising only a part of the acetabular region and the shaft. It has a large acetabulum as in other Palaeobatrachidae (Roček, 2013). The anteroventral margin of the acetabulum slightly exceeds the outline of the bone as in most other palaeobatrachids. The iliac shaft is thick, rounded, and only slightly bent in its proximal part. The supracetabular fossa is absent. In contrast to $P$. eurydices, the acetabular portion of the 
ilium is not inclined posteromedially, and the acetabulum opens mostly laterally. Moreover, a broad and deep depression between the shaft and pars acetabularis, which is known in $P$. eurydices, is absent. The pars ascendens is relatively wide, whereas the pars descendens is poorly developed and does not extend beyond the lower margin of the acetabulum. The tuber superior is elongated, prominent, and slightly inclined laterally. It is separated from the pars ascendens by a smooth oblique groove which continues onto the medial surface of the bone. The symphysial area is triangular with a medially prominent spina iliaca. The interiliac groove is wide.

\section{DISCUSSION}

Palaeobatrachus from Volchaya Balka and Gaverdovsky belongs to the family Palaeobatrachidae and Palaeobatrachus (sensu Roček, 2013), as shown by the presence of the following characters: parasphenoid extending beyond anterior border of sphenethmoid; long sphenethmoid, with the fenestra frontoparietalis more than half the total length of the bone with two parallel ridges delimiting the articulation area of the parasphenoid on the ventral surface; angular with the coronoid process either smooth or bearing muscle scars on the dorsal surface; vertebral centra strongly compressed dorsoventrally, with crescentic condyle and cotyle; $V_{7+8+9}$ fused to form synsacrum; urostyle without transverse processes and with poorly developed dorsal crest; clavicle with long extremitas glenoidalis; coracoid with processus rostriformis; short scapula, with the pars glenoidalis and pars acromialis not fully separated; humerus without fossa cubitalis ventralis, with a comparatively small humeral ball and epicondyles that are similar in size; ilium with a massive ascending part and with a large acetabulum extending anteroventrally beyond the margin of bone; strongly protruding symphysial area of the ilium.

Palaeobatrachus from Volchaya Balka and Gaverdovsky differs from all palaeobatrachids (where this character is known) in having four premaxillary teeth. The other species of Palaeobatrachus usually have a large number of premaxillary teeth (five or more teeth), which is characteristic mostly of Eocene - middle Miocene species ( $P$. tobieni, $P$. hiri, $P$. laubei, $P$. diluvianus, $P$. gigas, and $P$. grandipes), whereas reduced dentition (two or three teeth) is characteristic of Pleistocene species (P. eurydices). Polish Neogene Palaeobatrachus (Młynarski, 1977; Sanchíz and Młynarski, 1979) also displays a reduced number of tooth positions on the premaxilla, but its exact number of teeth is unclear. The number of maxillary teeth (about 1012 teeth) in Caucasian Palaeobatrachus is also strongly reduced in comparison with some older species (except $P$. laubei) and similar to that of younger species $(P$. eurydices with nine teeth and $P$. langhae with eight teeth). As in Pleistocene species, the dentigerous portion of the maxilla of Caucasian Palaeobatrachus terminates before (or slightly behind) the posterior end of the frontal process. Thus, the late Miocene Palaeobatrachus from Volchaya Balka and Gaverdovsky shows an intermediate morphology between Eocene - middle Miocene and Pleistocene Palaeobatrachus in the reduction of premaxillary and maxillary teeth (Figure 6). However, low number of maxillary teeth (eight teeth) is known in $P$. laubei from middle-late Oligocene (Špinar, 1972). It is not possible to exclude that a reduced number of teeth on the premaxilla and maxilla may be homoplastic features within Palaeobatrachus.

When compared to the Pleistocene species ( $P$. eurydices and $P$. langhae), Palaeobatrachus from Volchaya Balka and Gaverdovsky clearly differs from $P$. eurydices in the morphology of the sphenethmoid, that is, the presence of separated contact for the nasals, the presence of the median ridge and prominent lateral processes, the shape of the contact facet for the parasphenoid, and the presence of a well-developed extremitas spatulata of the angular, the smooth crista of the coracoid, and the acetabular portion of the ilium, which is not inclined posteromedially. It differs from $P$. langhae in the synsacrum comprising $V_{7+8+9}$ vertebrae and the urostyle without wings of $V_{10}$. In the former character Palaeobatrachus from Volchaya Balka and Gaverdovsky resembles to Pliocene Palaeobatrachus from Rębielice Królewskie (Poland; Młynarski, 1960).

Palaeobatrachus from Volchaya Balka and Gaverdovsky also differs from the early-middle Miocene species (P. robustus, P. hiri, and P. hauffianus). It differs from $P$. hiri in the not coalesced frontoparietal and parasphenoid, the straight or slightly concave orbital margin of the nasal; the wider processus posterodorsalis of the squamosal, the reduced number of tooth positions on the premaxilla and maxilla, and the synsacrum comprising $V_{7+8+9}$. It differs from $P$. robustus in the well-developed lateral extensions of sphenethmoid, the not clearly outlined frontoparietal table, and the welldeveloped transverse processes of $V_{7}$. It differs from $P$. hauffianus in the synsacrum comprising $V_{7+8+9}$. Comparison with the pre-Miocene species 


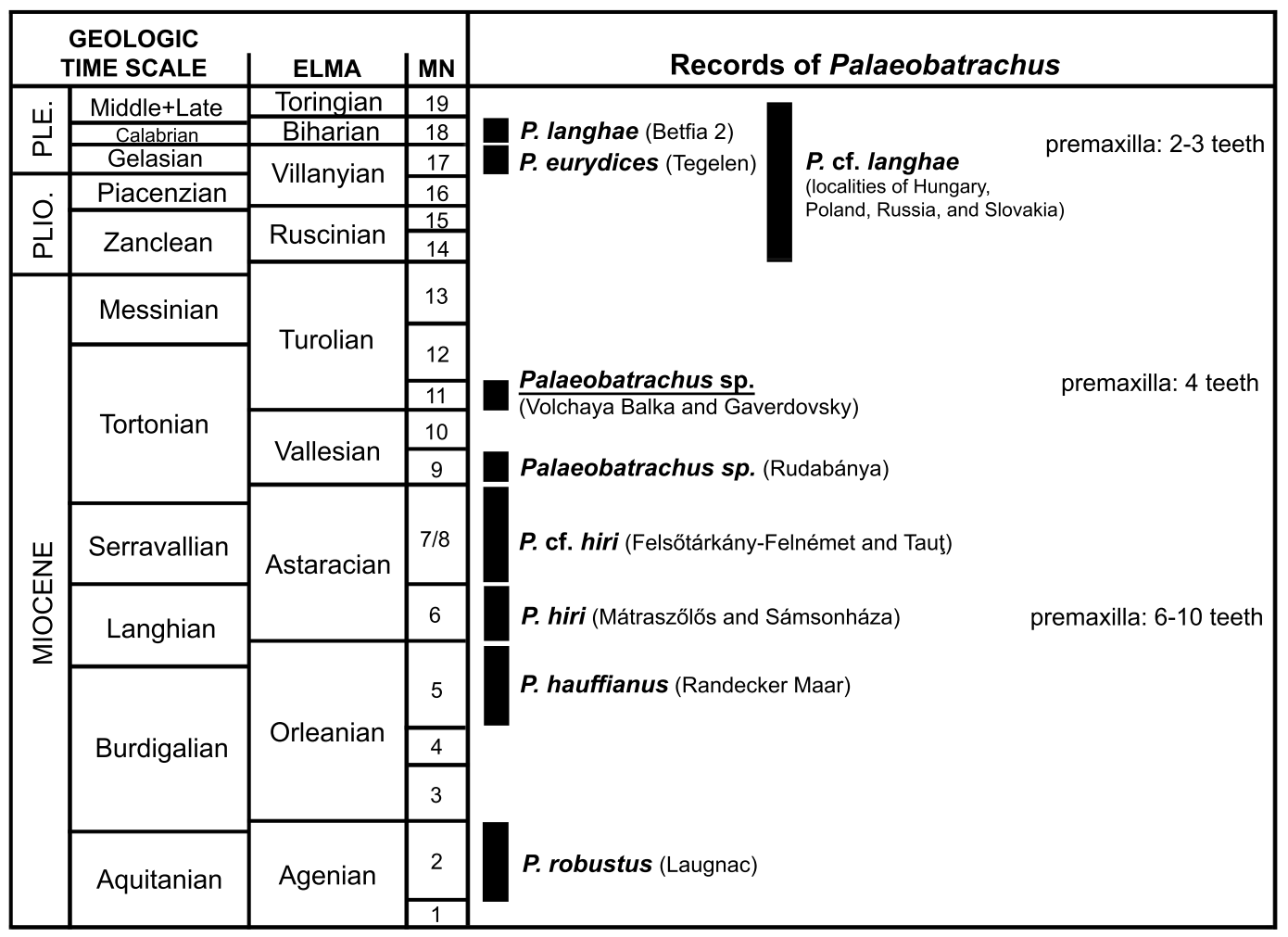

FIGURE 6. Geological distribution of Palaeobatrachus records in the Miocene-Pleistocene.

is difficult because they have been found only as two-dimensional specimens. Nevertheless, Palaeobatrachus from Volchaya Balka and Gaverdovsky differs from most of them (except $P$. diluvianus) in the synsacrum comprising $V_{7+8+9}$ with transverse processes of $V_{7}$, which are not reduced and contribute to the synsacral wings. The one specimen with only $\mathrm{V}_{8}$ and $\mathrm{V}_{9}$ fused together $\left(\mathrm{V}_{8+9}\right.$; Figure 4.10-12) may indicate that another species of Palaeobatrachus might have coexisted with Palaeobatrachus from Volchaya Balka and Gaverdovsky.

The morphology of the synsacrum together with the shape of the frontoparietal are among the most important characters of Palaeobatrachus (Roček et al., pers. comm., 2018). The low and widely spaced parasagittal ridges of the frontoparietal observed in Palaeobatrachus from Volchaya Balka and Gaverdovsky are typical for the Miocene-Pleistocene species. However, the presence of the pineal foramen together with the fenestrae between the pedicles of the synsacral wings may suggest that Palaeobatrachus from Volchaya Balka and Gaverdovsky belongs to the pedomorphic species. But the presence of the frontoparietal (Figure 1.12-14) and synsacrum (Figure 4.10-12), which differ from most of the corresponding elements, may indicate that two species of Palaeobatrachus coexisted in Volchaya Balka and Gaverdovsky. Due to the absence of the complete frontoparietal and difficulty with associating the fragmentary frontoparietals to a certain type of synsacrum, we avoid describing new species and consider Palaeobatrachus from Volchaya Balka and Gaverdovsky as Palaeobatrachus sp.

Palaeobatrachus from Volchaya Balka and Gaverdovsky shows extreme adaptation to permanent life in water (similar to pipids), which can be evidenced by the wide contribution of the transverse processes of $V_{7+8+9}$ in the sacral wings and absence of the fossa cubitalis ventralis on the humerus (see Villa et al., 2016; Hodrová, 1982b). Wide sacral wings provide support for a sliding articulation between the iliac shafts and the sacra, allowing fore and aft movements of the pelvis during swimming (Van Dijk, 2002; Wuttke et al., 2012). A shallow (or absence) fossa cubitalis ventralis does not correspond a flexion of the radioulna and humerus that serves as a damper in shock absorbing during the landing phase of the jump in frogs that move on dry land (Villa et al., 2016). A similar extreme adaptation to life in water is known in Pliocene and Pleistocene Palaeobatrachus; it is 


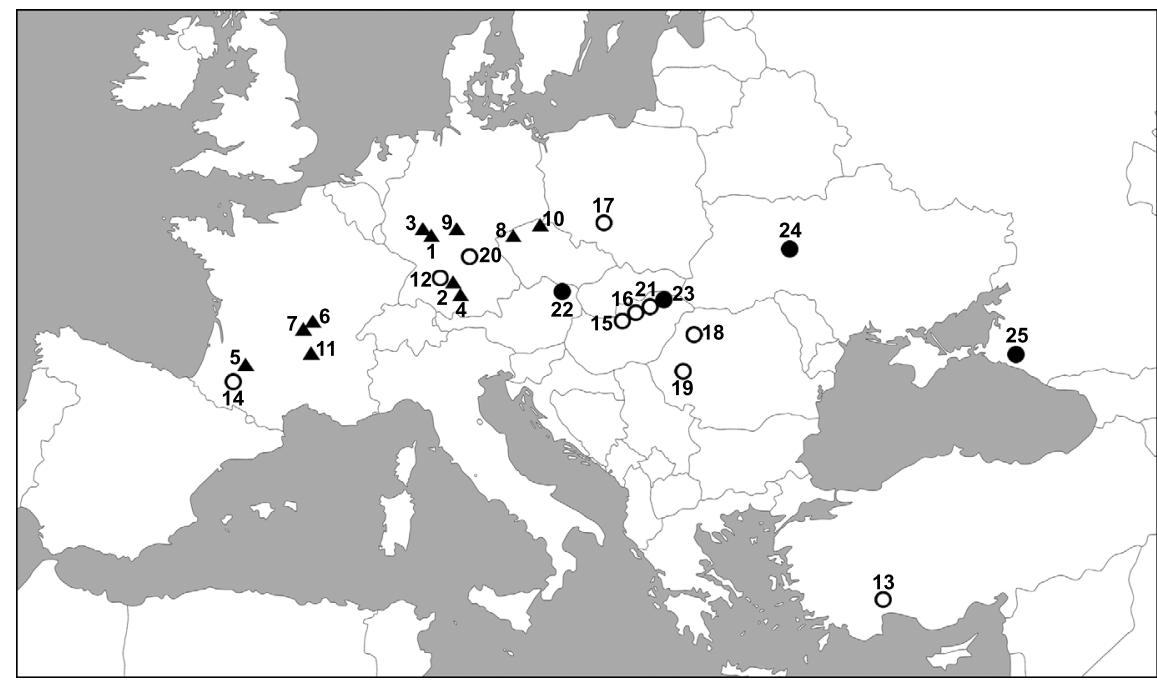

FIGURE 7. Occurrences of Palaeobatrachus in the early (black triangles), middle (white circles) and late (black circles) Miocene; based on Wuttke et al., 2012 (with changes): 1, Weisenau (early Miocene, MN 1) (Wolterstorf, 1887); 2, Tomerdingen (early Miocene, MN 1-2) (Dehm, 1935, Sanchiz, 1998, Rage and Roček, 2003); 3, Am Hambusch (= Dyckerhoff in Mainz-Amöneburg, or Kastel, Amöneburg, Biebrich, Hessler) (early Miocene, Aquitan to Burdigal, MN 2-3) (Schleich, 1988); 4, Haslach bei UIm (early Miocene, MN 2) (Wolterstorff, 1887); 5, Laugnac (early Miocene, MN 2) (Vergnaud-Grazzini and Hoffstetter, 1972, Hossini and Rage, 2000); 6, Poncenat (early Miocene, MN 2) (Rage and Roček, 2003; Hossini and Rage, 2000); 7, Saint-Gérand-le-Puy (early Miocene, MN 1-2) (Rage and Roček, 2003); 8, Hájek (= Grassengrün) near Karlovy Vary (early Miocene) (Špinar, 1972); 9, Kaltennordheim (early Miocene) (Wolterstorff, 1887); 10, Skyřice (= Skyritz) (early Miocene, MN 3) (Špinar, 1972); 11, Issoire (early Miocene, MN 1-5) (Rage and Roček, 2003); 12, Randecker Maar (middle Miocene, MN 5) (Roček et al., 2006); 13, Anatolia (early Miocene) (Claessens, 1997); 14, Sansan (Middle Miocene, MN 6) (Vergnaud-Grazzini and Hoffstetter, 1972; Hossini and Rage, 2000); 15, Mátraszölös 2 (middle Miocene, MN 6) (Venczel, 2004); 16, Sámsonháza (middle Miocene, MN 6) (Venczel, 2004); 17, Opole (middle Miocene, MN 7) (Młynarski et al., 1982); 18, Subpiatră 2/2 (middle Miocene, MN 7+8) (Hír and Venczel, 2005, Venczel et al., 2005); 19, Tauţ (late middle Miocene, MN 7+8) (Venczel and Ştiucă, 2008); 20, Adelschlag (late middle Miocene, MN 6-8) (Schlosser, 1916); 21, Felsőtárkány 3/10 and Felsőtárkány-Felnémet 2/3 (late Middle Miocene, MN 7+8) (Venczel and Hir, 2013); 22, Götzendorf/Sandberg (late Miocene, MN 9) (Harzhauser and Tempfer, 2004); 23, Rudabánya (late Miocene, MN 9) (Roček, 2005); 24, Gritsev (late Miocene, MN 9) (Wuttke et al., 2012; Vasilyan et al., 2016); 25, Volchaya Balka and Gaverdovsky (late Miocene, MN 11) (this paper).

suggested based on the absence of the fossa cubitalis ventralis, less developed olecranon on the radioulna ( $P$. eurydices; Villa et al., 2016), and wide contribution of the transverse processes of $\mathrm{V}_{7+8+9}$ in the sacral wings (Palaeobatrachus sp.; Hodrová, 1982b). Thus, palaeobatrachids probably reached an extreme degree of aquatic adaptation as early as the late Miocene or even earlier.

The general distributional shift of the palaeobatrachids to the east was suggested by Wuttke et al. (2012). According to this hypothesis, during the Paleogene, the palaeobatrachid record is restricted to Western and Central Europe. During the Miocene (Figure 7), palaeobatrachids began to shift to Eastern Europe and appeared in Anatolia (early Miocene; Claessens, 1997). In the late Miocene, palaeobatrachids became surprisingly rare and known only from the localities of the MN 9: Götzen-
dorf/Sandberg (Harzhauser and Tempfer, 2004), Rudabánya (Roček, 2005), and Gritsev (Wuttke et al., 2012; Vasilyan et al., 2016). In the Pliocene, palaeobatrachids reappeared (possibly from Siberia; Vasilyan et al., 2016) only in Eastern Europe (since the beginning of MN 14) and almost completely disappeared in Western and Central Europe. Only three occurrences do not fit this shift: the late Pliocene (MN 16a) locality Hambach 11 in northwest Germany (Mörs, 2002), the early Pleistocene locality Voigtstedt (Kretzoi, 1965), and the early Pleistocene locality Tegelen (Villa et al., 2016). Palaeobatrachus from Volchaya Balka and Gaverdovsky is the only late Miocene record in easternmost Europe (European Russia; Figure 7). It shows that these frogs widely occupied Eastern Europe since the beginning of the late Miocene. Moreover, Caucasian Palaeobatrachus partly fills the late Miocene gap (MN 10-13; Figure 6) in 
palaeobatrachid distribution, indicating that this gap is not real and can be explained by an incomplete fossil record.

\section{ACKNOWLEDGMENTS}

I would like to express my thanks to fellow members of the expeditions to the Volchaya Balka and Gaverdovsky locality for collecting specimens, assistance in the field, and collaboration: V.V. Titov and S.V. Kurshakov (Institute of Arid zones, SSC RAS, Rostov-on-Don, Russia), A.S. Tesakov and P.D. Frolov (Geological Institute, Russian Academy of Sciences, Moscow, Russia), N.V. Volkova (Paleontological Institute, Russian Academy of Sciences, Moscow, Russia), A.A. Lissovsky, E.V.
Obolenskaya and S.A. Tesakov (Moscow State University, Moscow, Russia), I.A. Kazanov (Belaya Kalitva polytechnic technical school, Belaya Kalitva, Russia). I greatly appreciate Prof. Dr. Z. Roček, (Geological Institute, Czech Academy of Sciences, Prague, Czech Republic) for providing literature and images of the holotype specimens of Palaeobatrachus diluvianus, $P$. gigas, $P$. grandipes and $P$. laubei and for revised data of species of Palaeobatrachus. I also thank R. Rakitov (Borissiak Paleontological Institute RAS, Moscow) for the help with SEM microscopy. The study was supported by the Russian Scientific Fund № 18-7410081 and the government theme AAAA-A17117030310017-8.

\section{REFERENCES}

Bieber, V. 1881. Über zwei neue Batrachier der böhmischen Braunkohlenformation. Sitzungsberichte der Akademie der Wissenschaften, mathematisch-naturwissenschaftliche Klasse, Abteilung 1, 82:102-124.

Blain, H.-A., Canudo, J.-I., Cuenca-Bescós, G., and López-Martinez, N. 2010. Amphibians and squamate reptiles from the latest Maastrichtian (Upper Cretaceous) of Blasi 2 (Huesca, Spain). Cretaceous Research, 31:433-466. https://doi.org/10.1016/j.cretres.2010.06.001

Blanco, A., Bolet, A., Blain, H.-A., Fondevilla, V., and Marmi, J. 2015. Late Cretaceous (Maastrichtian) amphibians and squamates from northeastern Iberia. Cretaceous Research, 57:624-638. https://doi.org/10.1016/j.cretres.2015.07.005

Bolkay, St. J. 1919. Osnove uporedne osteologije anurskih batrachija sa dodatkom o porijeklu Anura i sa skicom naravnog sistema istih. Glasnik Zemaljskog Muzeja Bosni Hercegovini, 31:353-377.

Buffetaut, E., Costa, G., Lel Loeuff, J., Martin, M., Rage, J.-C., Calentin, X., and Tong, H. 1996. An Early Campanian vertebrate fauna from the Villeveyrac Basin (Hérault, Southern France). Neues Jahrbuch für Geologie und Paläontologie, 1996:1-16.

Claessens, L.P.A.M. 1997. On the herpetofauna of some Neogene eastern Mediterranean localities and the occurrence of Palaeobatrachus and Bufo (Amphibia, Anura) in the lower Miocene of Turkey. Journal of Vertebrate Paleontology, 17:39A.

Cope, E.D. 1865. Sketch of the primary groups of Batrachia Salientia. Natural History Review, 5:97-120.

Dehm, R. 1935. Über tertiäre Spaltenfüllungen in Fränkischen und Schwäbischen Jura. Abhandlungen Bayerischen Akademie Wissenschaften. MathematischNaturwissenschaftliche Abteilung, 29:1-86.

Estes, R. and Sanchíz, B. 1982. New discoglossid and palaeobatrachid frogs from the Late Cretaceous of Wyoming and Montana, and a review of other frogs from the Lance and Hell Creek Formations. Journal of Vertebrate Paleontology, 2:9-20.

Fejérváry, G.J. 1917. Anoures fossiles des couches préglaciaires de Püspökfürdö en Hongrie. Földtani Közlöny, 47:141-199.

Fischer, G. 1813. Zoognosia tabulis synopticis illustrata, in usum praelectionum Academiae Imperialis Medico-Chirurgicae Mosquensis edita (vol. 1. 3rd ed.). Nicolai Sergeidis Vsevolzsky, Moscow.

Fraas, E. 1909. Rana Hauffiana n. sp. aus den Dysodilschiefern des Randecker Maares. Jahreshefte des Vereins für vaterländische Naturkunde in Württemberg, 65:1-7.

Gardner, J.D. 2008. New information on frogs (Lissamphibia: Anura) from the Lance Formation (late Maastrichtian) and Bug Creek Anthills (late Maastrichtian and early Paleocene), Hell Creek Formation, USA, p. 219-249. In Sankey, J.T. and Baszio, S. (eds.), Vertebrate 
Microfossil Assemblages: Their Role in Paleoecology and Paleobiogeography. Indiana University Press, Bloomington.

Giebel, C. 1851. Ueber eine neue Art von Palaeophrynos Tsch. aus dem Braunkohlengebilde des Siebengebirges. Jahresbericht des naturwissenschaftlichen Vereines in Halle, 3:44-48.

Goldfuss, G.A. 1831. Beiträge zur Kenntnis verschiedener Reptilien der Vorwelt. Nova Acta Physico-medica Academiae Caesarae Leopoldino-Carolinae, Naturae Curiosorum, 15:61128.

Harzhauser, M. and Tempfer, P.M. 2004. Late Pannonian wetland ecology of the Vienna Basin based on molluscs and lower vertebrate assemblages (Late Miocene, MN9, Austria). Courier Forschungsinstitut Senckenberg, 246:55-68.

Hír, J. and Venczel, M. 2005. New Middle Miocene vertebrate localities from Subpiatră (Bihor district, Romania). Acta Palaeontologica Romaniae, 5:211-221.

Hodrová, M. 1981. Plio-Pleistocene frog fauna from Hajnáčka and Ivanovce, Czechoslovakia. Věstnik Ústředního ústavu geologického, 56:215-224.

Hodrová, M. 1982a. The genus Pliobatrachus from the Upper Pliocene of Czechoslovakia. Casopis pro mineralogii a geologii, 27:37-49.

Hodrová, M. 1982b. Pliocene Frogs of the genus Pliobatrachus: Their mode of movement. Acta Universitatis Carolinae Geologica, 4:439-446.

Hossini, S. and Rage, J.-C. 2000. Palaeobatrachid frogs from the earliest Miocene (Agenian) of France, with description of a new species. Geobios, 33:223-231. https://doi.org/10.1016/ S0016-6995(00)80019-4

Kretzoi, M. 1965. Die Amphibien aus der altpleistozänen Fundstelle Voigtstedt in Thüringen. Paläontologische Abhandlungen Abteilung A, Paläozoologie, 2:325-333.

Meszoely, C.A.M., Špinar, Z.V., Ford, R.L.E. 1984. A new palaeobatrachid frog from the Eocene of the British Isles. Journal of Vertebrate Paleontology, 3:143-147.

Meyer, H. 1852. Mittheilungen an Professor Bronn. Neues Jahrbuch für Mineralogie, Geognosie, Geologie und Petrefacten-Kunde, 1852:465-468.

Młynarski, M. 1960. Pliocene amphibians and reptiles from Rębielice Królewskich (Poland). Acta Zoologica Cracoviensa, 5(4):131-153.

Młynarski, M. 1962. Notes on the amphibian and reptilian fauna of the Polish Pliocene and Early Pleistocene. Acta Zoologica Cracoviensa, 7:177-194.

Młynarski, M. 1977. New notes on the amphibian and reptilian fauna of the Polish Pliocene and Pleistocene. Acta Zoologica Cracoviensa, 22:13-36.

Młynarski, M., Szyndlar, Z., Estes, R., Sanchiz, B., 1982. Lower vertebrate fauna from the Miocene of Opole (Poland). Estudios Geologicos, 38:103-119.

Mörs, T. 2002. Biostratigraphy and paleoecology of continental Tertiary vertebrate faunas in the Lower Rhine Embayment (NW-Germany). Netherlands Journal of Geosciences. Geologie en Mijnbouw 81:177-183. https://doi.org/10.1017/S0016774600022411

Rage, J.-C. and Roček, Z. 2003. Evolution of anuran assemblages in the Tertiary and Quaternary of Europe, in the context of palaeoclimate and palaeogeography. AmphibiaReptilia, 24:133-167. https://doi.org/10.1163/156853803322390408

Ratnikov, V.Yu. 1993. The first finding of Pliobatrachus (Anura, Palaeobatrachidae) in Muchkapian sediments of the basin of upper River Don. Paleontological Journal, 1993:130-132. (In Russian, with English summary)

Ratnikov, V.Yu. 1997. On the finds of Pliobatrachus (Anura, Palaeobatrachidae) in Eastern Europe. Paleontological Journal, 1997:70-76. (In Russian, with English summary)

Ratnikov, V.Yu. 2002. Late Cenozoic amphibians and squamate reptiles of the East-European Platform. Trudy Nauchno-Issledovatelskogo Instituta Geologii Voronezhskogo Universiteta, Voronezh, 10:1-138. (In Russian)

Roček, Z. 2005. Late Miocene Amphibia from Rudabánya. Palaeontographia Italica, 90:11-29.

Roček, Z. 2013. Mesozoic and Tertiary Anura of Laurasia. Palaeobiodiversity and Palaeoenvironments, 93:397-439. https://doi.org/10.1007/s12549-013-0131-y

Roček, Z. 2016. "Lost" and rediscovered: Holotype of Palaeobatrachus diluvianus (Goldfuss, 1831). Fossil Imprint, 72(1-2):45-52. https://doi.org/10.14446/FI.2016.45

Roček, Z., Boistel, R., Lenoir, N., Mazurier, A., Pierce, S.E., Rage, J.-C., Smirnov, S.V., Schwermann, A.H., Valentin, X., Venczel, M., Wuttke, M., and Zikmund, T. 2015. Frontoparietal bone in extinct Palaeobatrachidae (Anura): its variation and taxonomic value. The Anatomical Record, 298:1848-1863. https://doi.org/10.1002/ar.23203 
Roček, Z., Böttcher, R., and Wassersug, R. 2006. Gigantism in tadpoles of the Neogene frog Palaeobatrachus. Paleobiology, 32:666-675. https://doi.org/10.1666/05073.1

Roček, Z. and Wuttke, M. 2010. Amphibia of Enspel (Late Oligocene, Germany). Palaeobiodiversity and Palaeoenvironments, 90:321-340. https://doi.org/10.1007/s12549010-0042-0

Sanchiz, B. 1998. Encyclopedia of Paleoherpetology, Part 4, Salientia. Verlag Dr. Friedrich Pfeil, München.

Sanchíz, B. and Młynarski, M. 1979. Remarks on the fossil anurans from the Polish Neogene. Acta Zoologica Cracoviensia, 24:175-188.

Schleich, H.H. 1988. Paläoherpetologische Materialien und Faunenspektren aus dem Kalktertiär des Mainzer Beckens (Oberoligozän-Untermiozän). Geologisches Jahrbuch, A 110:289-306.

Schlosser, M. 1916. Neue Funde fossiler Säugetiere in der Eichstätter Gegend. Abhandlungen der königlich Bayerischen. Akademie der Wissenschaften, Mathematisch-physikalische Klasse, 28(6):1-78.

Smith, R. 2003. Les vertébrés terrestres de l'Oligocène inférieur de Belgique (Formation de Borgloon, MP 21): inventaire et interpretation des données actuelles. Coloquios de Paleontología, 1:647-657.

Špinar, Z.V. 1972. Tertiary Frogs from Central Europe. Academia, Prague.

Syromyatnikova, E.V. 2016. Late Miocene anuran fauna from Volchaya Balka locality (north Caucasus, Russia), p. 224. In Holwerda, F., Madern, A., Voeten, D., van Heteren, A., Liston, J., Meijer, H., and den Ouden, N. (eds.), XIV Annual Meeting of the European Association of Vertebrate Palaeontologists. Haarlem, the Netherlands.

Szentesi, Z. and Company, J. 2016. Late Maastrichtian small-sized herpetofauna from Valencia province, eastern Spain. Historical Biology, 29(1):1-10. https://doi.org/10.1080/ 08912963.2015 .1122004

Tesakov, A.S., Titov, V.V., Simakova, A.N., Frolov, P.D., Syromyatnikova, E.V., Kurshakov, S.V., Volkova, N.V., Trichunkov, Y.I., Sotnikova, M.V., Kruskop, S.V., Zelenkov, N.V., Tesakova, E.M., and Palatov, D.M. 2017. Late Miocene (Early Turolian) vertebrate faunas and associated biotic record of the Northern Caucasus: geology, taxonomy, paleoenvironment, biochronology. Fossil Imprint, 73(3-4):383-444.

Tschudi, J.J.V. 1838. Classification der Batrachier mit Berücksichtigung der fossilen Thiere dieser Abtheilung der Reptilien. Neuchâtel, Petitpierre.

van den Hoek Ostende, L., van Bennekom, L., Gardner, J.D., Alçiçek, M.C., Murray, A., Wesselingh, F.P., Alçiçek, H., and Tesakov, A. 2015. Ericek, a new Pliocene vertebrate locality in the Çameli Basin (southwestern Anatolia, Turkey). Palaeobiodiversity and Palaeoenvironments, 95:305-320. https://doi.org/10.1007/s12549-015-0202-3

Van Dijk, E. 2002. Longitudinal sliding articulations in pipid frogs. South African Journal of Science, 98:555-556.

Vasilyan, D., Zazhigin, V., and Böhme, M. 2016. Neogene amphibians and reptiles (Caudata, Anura, Gekotta, Lacertilia, Testudines) from south of Western Siberia, Russia and Northeastern Kazakhstan. PeerJ, 5:e3025. https://doi.org/10.7287/peerj.preprints.2365v1

Venczel, M. 2000. Amphibians from the Lower Pleistocene Betfia 9 locality (Bihor County, Romania). Satu Mare - Studii şi comunicări, Ştiinţele naturii, 1:28-37.

Venczel, M. 2001. Anurans and squamates from the Lower Pliocene (MN14) Osztramos 1 locality (Northern Hungary). Fragmenta Paläontol Hungarica, 19:79-90.

Venczel, M. 2004. Middle Miocene anurans from the Carpathian Basin. Palaeontographica Abteilung A, 271:151-174.

Venczel, M., Codrea, V., and Fărcaş, C. 2013. A new palaeobatrachid frog from the early Oligocene of Suceag, Romania. Journal of Systematic Palaeontology, 11(2):179-189. https:/ /doi.org/10.1080/14772019.2012.671790

Venczel, M. and Hír, J. 2013. Amphibians and squamates from the Miocene of Felsőtárkány Basin, N-Hungary. Palaeontographica Abteilung A, 300:117-158. https://doi.org/10.1127/ pala/300/2013/117

Venczel, M., Hír, J., Huza, R.R., Popa, E., Golban, D. 2005. A new Middle Miocene vertebrate fauna from Subpiatrã (Bihor County, Romania). Nymphaea, 32:23-38.

Venczel, M. and Sţiucă, E. 2008. Late middle Miocene amphibians and squamate reptiles from Tauţ, Romania. Geodiversitas, 30:731-763. 
Vergnaud-Grazzini, C. and Hoffstetter, R. 1972. Présence de Palaeobatrachidae (Anura) dans des gisements tertiaires français. Caractérisation, distribution et affinités de la famille. Palaeovertebrata, 5:157-177.

Vergnaud-Grazzini, C. and Mlynarski, M. 1969. Position systématique du genre Pliobatrachus Fejérváry, 1917. Comptes Rendus des Seances de l'Academie des Sciences, 268:23992402.

Villa, A., Roček, Z., Tschopp, E., van den Hoek Ostende, L.W., and Delfino, M. 2016. Palaeobatrachus eurydices, sp. nov. (Amphibia, Anura), the last western European palaeobatrachid. Journal of Vertebrate Paleontology, 36(6):e1211664. https://doi.org/ 10.1080/02724634.2016.1211664

Wolterstorff, W. 1886. Ueber fossile Frösche insbesondere das Genus Palaeobatrachus. I Theil. Jahresberichte und Abhandlungen des Naturwissenschaftlichen Vereins Magdeburg, 1885:1-94.

Wolterstorff, W. 1887. Ueber fossile Frösche insbesondere das Genus Palaeobatrachus. II Theil. Jahresbericht und Abhandlungen des Naturwissenschaftlichen Vereins in Magdeburg, 1886:1-81.

Wuttke, M., Přikry, T., Ratnikov, V.Y., Dvořák, Z., Roček, Z. 2012. Generic diversity and distributional dynamics of the Palaeobatrachidae (Amphibia: Anura). Palaeobiodiversity and Palaeoenvironments, 92:367-395. https://doi.org/10.1007/s12549-012-0071-y 